\title{
Tarptautinių katalogavimo principų (ICP) ataskaita
}

\author{
Barbara B. TILLETT \\ Kongreso biblioteka, Vašingtonas, JAV, el. p. btilloc.gov
}

Jau daugeli dešimtmečil IFLA yra tarptautiniı bibliografijos standartu centras. $1961 \mathrm{~m}$. Paryžiuje IFLA surenge katalogavimo ekspertu pasitarimq, kurio rezultatas buvo gerai žinomi Paryžiatıs principai. Jais grindžiamos beveik visos pagrindinés šiuo metu pasauliniu mastu taikomos katalogavimo taisyklès. Tai buvo nepaprastai svarbus żingsnis link katalogavimo praktikos tarptautinio suderinamumo, kuris iki šol tebera garbingas IFLA tikslas. Naujieji tarptautiniai katalogavimo principai jau paskelbti, jie atspindi viso pasaulio katalogavimo taisykliu rengèju ir ekspertu nuomonę.

Reikšminiai žodžiai: tarptautiniai katalogavimo principai.

$2001 \mathrm{~m}$. Natalija Kasparova iš Rusijos valstybinès bibliotekos priminè Katalogavimo sekcijai, kad nuo Paryžiaus principų paskelbimo jau praejjo 40 metụ ir kad atèjo laikas juos peržiūrèti atsižvelgiant $\mathrm{i}$ šiandienos kontekstą. Šio priminimo pasekmè buvo keletas pasaulyje surengtu regioniniu pasitarimu. Regioniniuose IFLA pasitarimuose buvo siekiama praplèsti keitimosi katalogavimo informacija pasauliniu mastu galimybes skatinant standartu̧ skirtų bibliotekų katalogus sudarančių bibliografinių ir autoritetiniu irašų turiniui, plètrą.

Buvo siekiama:

- parengti, o véliau - peržiūrèti ir atnaujinti $2003 \mathrm{~m}$. Frankfurto pasitarimo principu išdèstymo projekta, paskutinis projektas yra $2005 \mathrm{~m}$. rugsèjo mèn.;

- išsiaiškinti, ar imanomas didesnis sutarimas dẻl katalogavimo praktikos;

- parengti rekomendacijas dél galimų būsimu tarptautinių katalogavimo taisyklių. Tai būtų taisyklių rengejjams skirtos taisyklẻs, nustatančios normas, kurios bendru sutarimu būtų privalomos visoms katalogavimo taisyklèms.

$2007 \mathrm{~m}$. baigèsi penkiu regioniniu pasitarimu ciklas. Pirmasis ju surengtas 2003 m. Frankfurte, Vokietijoje, ir buvo skirtas Europos ir AACR katalogavimo taisykliu rengejjams bei katalogavimo ekspertams.

Pirmajame pasitarime dalyvavo 54 ekspertai iš 32 Europos šalių, taip pat ivairių taisykles kuriančiu organizacijų atstovai (buvo lyginama 16 taisyklių rinkiniu), AACR rengejjụ atstovai iš Jungtinès Karalystès, Australijos ir Jungtinių Valstiju (Kanada taip pat turi savo atstovą AACR2 komitete, tačiau jis i Frankfurto pasitarimą neatvyko).
Antrajame regioniniame pasitarime, ivykusiame 2004 m. rugpjūčio mèn. Buenos Airèse, Argentinoje, buvo užsiregistravę 45 dalyviai, tarp jų - 14 Lotynų Amerikos ir Karibu šalių atstovų. Internetinése diskusijose dalyvavo dar ir kitu šaliu atstovai. Siame pasaulio regione nèra nè vienos taisykles kuriančios organizacijos, o pagrindinès šio regiono šalyse taikomos taisyklès yra AACR2 arba prancūzú AFNOR. Pasitarimas vyko anglụ ir ispanu kalbomis, šiomis kalbomis buvo skelbiama ir jo medžiaga.

Trečiajame regioniniame pasitarime, surengtame 2005 m. gruodžio mèn. Kaire, Egipte, buvo užsiregistravę 95 dalyviai, tarp ju-atstovai iš 17 arabiškai kalbančiu Artimuju Rytụ šaliu. Internetinèse diskusijose ir balsavime dèl rekomenduojamu projekto pakeitimu bei ICP žodyno dalyvavo ir kitos šalys. Šiame regione irgi nèra taisykles kuriančių organizacijų, o daugelyje šalių taikomos AACR2 arba prancūzų AFNOR. Šio pasitarimo ataskaita prieinama anglu ir arabụ kalbomis.

Ketvirtasis IME ICC pasitarimas buvo skirtas Azijos taisyklių rengèjams ir katalogavimo ekspertams. 44 iš ju dalyvavo $2006 \mathrm{~m}$. rugpjūčio mèn. Seule, Korejjoje, surengtame pasitarime, kuris vyko Korejjos nacionalinèje bibliotekoje. Jame buvo atstovaujama taisykles kuriančioms organizacijoms iš Japonijos, Korèjos ir Kinijos. Pasitarimas vyko anglu, japonu, kinų ir korẻjiečių kalbomis.

Penktasis ir paskutinis IME ICC pasitarimas įvyko $2007 \mathrm{~m}$. rugpjūčio mèn. ir buvo skirtas Afrikos šalims, esančioms i pietus nuo Sacharos. Pasitarimą organizavo Pietu Afrikos nacionaline biblioteka Pretorijoje. Jame dalyvauti buvo pakviesti 53 katalogavimo ekspertai iš 27 šalių. Šiame regione taip pat nèra taisykles kuriančiu organizaciju, ir daugelyje šalių taikomos AACR, prancüzų 
AFNOR arba ISBD. Pasitarimas vyko angly kalba, o jo medžiaga prieinama anglu, prancūzu ir portugalų kalbomis.

Kiekvienam IME ICC pasitarimui skirtos interneto svetainès visomis to pasitarimo kalbomis. Šiose svetainèse skelbiamos kai kurių šalių ataskajtos ir pranešimų, principų bei žodyno vertimai. Visos svetainès prieinamos IFLANET.

Susitarimo dèl principụ ir susijusių tikslų bei pagrindiniụ taisyklių proceso pradžioje buvo parengtas dokumento projektas kartu su pridedamuoju žodynu, jie buvo aptariami kiekvieno pasitarimo metu, o po kiekvieno pasitarimo buvo balsuojama dèl alternatyvios redakcijos ir pasiūlymų. Proceso pabaigoje buvo bendrai susitarta dél teksto redakcijos, taip pat žodyno terminu ir apibrěžčių ivairiomis kalbomis. Didelémis pastangomis buvo pasiektas ta pačia kalba kalbančių šalių susitarimas dèl terminų, ypač tai susiję su anglų, prancūzцุ, ispanı ir portugalu kalbomis.

Susitarimas buvo pasiektas baigiamuoju balsavimu $2008 \mathrm{~m}$. gruodžio mèn., o patvirtinti principai ir žodynas paskelbti IFLANET $2009 \mathrm{~m}$. vasario mèn.

Leidinyje IFLA Cataloguing Principles; the Statement of International Cataloguing Principles (ICP) and its Glossary, išleistame „Saur" leidyklos, paskelbti principaj ir jų žodynas, taip pat principu ir ICP žodyno vertimai $i 20$ kalbų. Jame yra skyrius, kuriame nušviečiamas rengimo procesas, pateikiamos daugelio organizatoriu ir rémèju padèkos, taip pat dalyvių iš ivairių šalių nuotraukos.

Principus sudaro šse skyriai:

Ižanga;

1. Taikymo sritis;

2. Bendrieji principai;

3. Entitetai, atributai ir santykiai;

4. Katalogo tikslai ir funkcijos;

5. Bibliografinis aprašas;

6. Kreipties elementai;

7. Paieškos galimybių pagrindai;

ICP žodynas.

Atkreipiame démesi, kad skyriai apima ne tik bendruosius principus, bet ir tikslus, siūlomas taisykles, taip pat principц žodyną.

Ižangoje nurodoma, kađ šie principai taikomi visų rūšit medžiagai aprašyti ir prieigai prie jos, - skirtingai negu Paryžiaus principai, kurie buvo skirti daugiausia tekstams. Šie naujieji principai taikomi ne tik pirmojo elemento pasirinkimui ir jo formai, bet ir prieigai, ir ne tik bibliografiniams įrašams, bet ir autoritetiniams irašams. Principuose teigiama, kad jie remiasi turtingomis pasaulio katalogavimo tradicijomis ir FRBR bei FRAD konceptualiais modeliais, taip pat FRSAR. Visa tai sudaro principu pagrindą, ir mes ketiname laikytis pamatiniu informacijos organizavimo, kontroliuojamos prieigos teikimo bei bibliografinių santykių nuostatı.
Pasak Elaine Svenonius', principai yra bibliografinès kalbos, vartojamos bibliografinei sistemai kurti, konstravimo direktyvos. Principai yra taisykliu rengimo gairès; tikslai yra tai, kokias funkcijas mes norétume priskirti sistemai, pavyzdžiui, padèti vartotojams rasti visus išteklius, susijusius su asmeniu; o taisyklẻs yra specifinès gairès šiems tikslams pasiekti.

$1961 \mathrm{~m}$. Paryžiaus principais buvo siekiama maksimaliai išnaudoti kortelinio katalogo technologines galimybes pateikiant pagrindinius irašus ir papildomuosius irrašus.

Naujieji katalogavimo principai apima ir bibliografinius, ir autoritetinius ịrašus, taip pat visas išteklių rūšis. Kadangi principai skirti taisykliụ kūrẻjams, iš pradžių pateikiama katalogavimo principus pagrindžianti bendroji nuostata pirmiausia galvoti apie vartotoja.

Norètume, kad būsimos taisyklès būtų nesunkiai suprantamos ir apimtų tik tick metaduomenı̧, kiek reikalinga vartotojo užduotims atlikti, atitiktų iprastos vartosenos, išsamumo, būtinumo, ekonomijos principus - nurodytų pateikti tikslius duomenis ir minimalų skaičių reikalingų elementu, identifikuojančių išteklius. Tikslumo ir iprastos vartosenos principu taip pat grindžiamas būtinumas aprašyti jšteklius ir pateikti vardụ formas taip, kaip yra pačiame ištekliuje, ir šiuos duomenis naudoti ištekliams identifikuoti. Be to, kataloguotojas turi itraukti duomenis, kurie padètน orientuoti vartotoją i susijusius išteklius, todèl duomenys turi būti nuoseklūs, standartizuoti ir suteikti integralumo. Jei tam tikru atveju kataloguotojui atrodo, kad principai vienas kitam prieštarauja, jis turi priimti pagrịsta, praktišką sprendimą. Principais siekiama padèti kataloguotojuj nuspręsti, kaip aprašyti bibliografinius išteklius ar sukurtj prieiga prie ju.

Toliau ICP apibūdinami tikslai, t. y. katalogo funkcijos, igalinančios atlikti specifines vartotojo užduotis. Šje tikslai grindžiami FRBR vartotojo užduotimis rasti, identifikiuoti, atrinkti ir gauti, taip pat papildoma užduotimi - padèti vartolojams, tyrinèjantiems bibliografini universuma, orienthotis bibliografiniuose irašuose ir autoritetiniuose duomenyse.

Siuo atveju rasti reiškia turèti galimybę rasti visus išteklius, susijusius su tam tikru asmeniu, arba rasti konkretu kūrini.

Identifikuoti reiškia pateikti pakankamai entitetą aprašančių duomenų, pavyzdžiui, kad būtụ galima atskirti asmenis, turinčius toki pat vardą, papildomai gali būti užrašomos svarbios datos.

Atrinkti reiškia suteikti vartotojui galimybę pasirinkti išteklių, atitinkantị jo reikmes tam tikrai turinio rūšiai arba tam tikrai laikmenai, pavyzdžiui, knyga ar skaitmeninę versijin.

\footnotetext{
'Svenonjus, Elainc. The Intellectual Foundation of Imformation Organization. Cambridge, MA: MIT Press, 2000, p. 67-68.
} (ISBN 0.262-19433-3). 
[sigyti arba gauti reiškia suteikti informaciją taip, kad vartotojas galètu faktiškai gauti vienetą naudojimui, pamatyti skaitmeninę versiją arba sužinoti, kaip nusipirkti ar pasiskolinti egzempliorių.

Orientavimas priklauso nuo santykiu pateikimo ir logiško duomenų išdèstymo atvaizduojant, kad vartotojui būtu aiškiai nurodomas kelias, kaip rasti susijusius kūrinius, išraiškas, apraiškas, vieneta, susijusius asmenis, kolektyvus ar gimines, squvokas, objektus, ivykius ar vietas.

5 ir 6 skyriai labiau primena konkrečias taisykles, skirtas bibliografiniam aprašui ir kreiptjes elementams.

Rengiant bibliografinị aprašą nurodoma laikytis tarptautiniu lygiu pripažinto standarto; bibliotekoms toks standartas yra ISBD.

Nurodoma, kad kreipties elementai turi būti sudaromi laikantis principu ir kad turi būti užrašomos aprobuotos formos, formų variantai ir identifikatoriai.

Toliau nurodoma, kad aprobuotiems krejpties elementams (kurie seniau buvo vadinami aprobuotais pradmenimis) sudaryti turi būti vartojama ta kalba ir rašto sistema, kuri randama apraiškose originalo kalba ir rašto sistema, tačiau jiems sudaryti gali būti vartojama kalba ir rašto sistema, labiausiai tinkanti vartotojams. Nurodoma, kad, jei imanoma, per kreipties elementą turi būti suteikiama prieiga originalo kalba ir rašto sistema ir kad transliteracija i kitas rašto sistemas turi atitikti tarptautini rašto konversijos standarta.

Taip pat pateikiamos taisyklès, nurodančios, kuri vardą vartoti kaip aprobuota kreipties elementa, iš esmès leidžiančios pasirinkti tik vieną iš daugelio esamu ir teikti pirmenybę tam vardui, kuris dažniausiai vartojamas apraišskose arba yra gerai žinomas, priimtinas katalogo vartotojams. Kiti vardai turi būti itraukiami kaip vardų variantai, vartojami tolesnei paieškai.

Jei laikui bėgant pasikeičia kolektyvu vardai, jie turi būti susiejami nuorodomis.

Pasirenkant vardo pirmaji žodį būtina laikytis tos šalies ir kalbos, kuri labiausiai susijusi su entitetu, normu ir pateikti papildomı identifikuojančių požymių, kurie padètŭ diferencijuoti vardus.

Baigiamajame skyriuje aptariamos paieškos galimybès. Išvardijami 6 esminiai kreipties elementai (arba kiti pateiktini elementai) bibliografiniams irašams, pradedant aprobuotu kreipties elementu kūrejjo vardui arba pirmajam ivardytam kūrinio kūrèjui, taip pat pagrindinè antraštè, išleidimo ar publikavimo metai, kontroliuojami kürinio dalykiniai terminai ir (arba) klasifikaciniai indeksai, taip pat standartiniai numeriai, identifjkatoriai ir registracinès antraštès.

Esminiai kreipties elementai autoritetiniams irašams yra entiteto aprobuotas vardas ar antrašté, entiteto identifikatoriai, entiteto vardu variantai ir vardo ar antraštės formu variantai.

Tiek bibliografiniams, tiek autoritetiniams irašams siūloma sudaryti papildomus kreipties elementus publikavimo vieta, turinio rūšis, laikmenos rūšis, kuriuos kai kurios bibliotekos gali laikyti privalomais. Galiausiai primenama, kad atvaizduojami duomenys turi būti pateikiami logine seka, kuri būtu patogi vartotojui, pageidautina, pagal standarta, atitinkanti krejpties elementu ir atvaizduojamu duomenų kalbą ir rašto sistema.

Dabar, kai IFLA nustaté standarta, juo grindžiamu taisykliu kūrimas ir priežiūra priklauso nuo kitų institucijų. Kaip tik tai keleta mety buvo daroma Italijoje, ir $2008 \mathrm{~m}$. buvo paskelbtos naujos tos šalies katalogavimo taisyklès. Taip pat AACR priežiūros komitetas laikè, kad būtina parengti katalogavimo taisykles, kurios savo pobūdžiu būtu labiau tarptautinès. Konferencijoje, skirtoje AACR2 ateities perspektyvoms, ivykusioje 1997 m. Toronte, Kanadoje, Jungtinis vykdomasis komitetas inicijavo projekta, skirta naujų taisykliu, pavadintu RDA: Resource Description and Access, rengimui. Šios taisyklès grindžiamos IFLA principais, FRBR ir FRAD konceptualiais modeliais, taip pat ISBD. Jos rengiamos atsižvelgiant i žiniatinklyje pateikiamos informacijos ateiti, tačiau gali būti taikomos ir korteliniams katalogams arba net knyginiams katalogams ar kitoms bibliografinès apskajtos priemonèms.

IFLA veikla, skirta bibliografinės apskaitos pagrindams, tebèra svarbi plètojant keitimąsi bibliografiniais ir autoritetiniais duomenimis tarptautiniu lygiu. Pastarojo dešimtmečio IFLA pasiekimai džiugina, ir tikiuosi, kad IFLA ir toliau vadovaus šiai pasauliniu mastu svarbiai veiklai, kurios tikslas - teikti tobulesnes paslaugas vartotojams.

\section{Iš anglu kalbos verté T. Auškalnis}

Parengta pagal pranešima, skaitytą $2009 \mathrm{~m}$. Milane (Italjja) vykusioje 75-ojoje IFLA konferencijoje. 